\title{
To Be or Not to Be ...? Part III: Diesel versus Electrically Powered Cars
}

\author{
Ilia Brondz \\ Norwegian Drug Control and Drug Discovery Institute (NDCDDI), Ski, Norway \\ Email: ilia.brondz@gmail.com
}

How to cite this paper: Brondz, I. (2018) To Be or Not to Be ...? Part III: Diesel versus Electrically Powered Cars. Voice of the Publisher, 4, 33-50.

https://doi.org/10.4236/vp.2018.43004

Received: August 7, 2018

Accepted: September 7, 2018

Published: September 10, 2018

Copyright $\odot 2018$ by author and Scientific Research Publishing Inc.

This work is licensed under the Creative Commons Attribution-NonCommercial International License (CC BY-NC 4.0). http://creativecommons.org/licenses/by-nc/4.0/

\section{(c) (i) \& Open Access}

\begin{abstract}
$\mathrm{X} 5$ and 335d model diesel cars built by Bayerische Motoren Werke Aktiengesellschaft (BMW AG) between 2009 and 2011 were sued in a USA court in New Jersey for creating more pollution on the roads than in laboratory tests. BMW AG used testing methods similar to those admitted to by Volkswagen AG for cheating authorities (https://www.bloomberg.com/news/articles/2018-03-27/bmw-sued-for-install ing-defeat-devices-in-u-s-diesel-cars) [1]. Other manufacturers of diesel driven cars, for example, Ford Motor Co., Mercedes-Benz, Fiat Chrysler Automobiles NV, General Motors Co., and Volkswagen, have also produced diesel driven cars with higher levels of environmental pollution caused by sulfur oxides and NOx in exhaust gasses than is permissible. These companies have also met with similar problems and legal accusations. Was all this only the fault of the diesel car manufacturers, or was it perhaps a well-prepared attempt to discredit the diesel cars as they are or maybe the diesel motor as it is? Was it an attempt to favor the electric driven cars by undermining the manufacturers of diesel driving cars, and even possibly by undermining all manufacturers of cars driven by internal combustion engines (ICEs)? Diesel driven vehicles as a type of motor driven means are very powerful and economical and can be environmentally cleaner than other motor driven media, including electrically driven vehicles, if the total pollution produced by such vehicles is taken into account. The total manufacturing pollution from motor driven means, the handling, and the production of the driving force (e.g., benzene, kerosene, gasoline, diesel, and electricity) should all be taken into account. The environmental safety of the utilization of motor driven means and parts thereof after such vehicles have been decommissioned is also a very important consideration. The health hazards and environmental safety associated with the production, handling, and decommissioning must be considered as significant factors in the ranking of motor driven vehicles as a contributor to environmental pollution and health hazards.
\end{abstract}




\section{Keywords}

Diesel Driven Vehicles, Electrical Driven Vehicles, Environmental Safety, Health Hazards, Total Pollution, Polluting Factors

\section{Introduction}

\subsection{Historical Overview}

In the early days of human civilization, humans used different tools to help obtain life necessities. Muscle power (including the use of slave labor) was insufficient. The domestication of animals, such as the donkey or ass (Equus africanus asinus) [2], took place in ancient Egypt and Mesopotamia at around 3.000 BC in an attempt to improve the speed and efficiency of transport, in comparison what could be achieved with the ox (bull) [3]. An ox is a castrated bull; a bull is an intact, uncastrated adult male of the species Bos taurus [4]. In the late Pleistocene/early Holocene age, during the Neolithic period, several species related to the aurochs (today an extinct species) were domesticated, leading to the present-day zebu, water buffalo, yak, banteng, and taurine cattle. The aurochs of Eurasia and Northern Africa are the wild ancestors of modern cattle.

Between about 10,000 and $8000 \mathrm{BC}$, on the Indian subcontinent and in the Near East, aurochs were domesticated. The powerful ox was used for transport purposes; however, it is slow moving and requires a large amount of forage. The donkey was faster moving and required less forage, but it could not carry as much load as the ox. Domestication of the horse emerged as a good solution to this problem. The domestication of horse dates to between $4000 \mathrm{BC}$ and 3000 BC. The horse belongs to the order Perissodactyla, family Equidae, genus Equus, species $E$. ferus, and subspecies E. f. caballus. It is believed that the camel was domesticated in Africa around $3000 \mathrm{BC}$ and in Bactria in Central Asia around $2500 \mathrm{BC}$. The camel is suited to desert habitats, where it is used as a working animal. It belongs to the order Artiodactyla, family Camelidae, tribe Camelini, genus Camelus. Three species are living today: Camelus bactrianus, Camelus dromedarius, and Camelus ferus. Three other species are known as fossils: $\mathrm{Ca}$ melus gigas, Camelus moreli, and Camelus sivalensis. There are several other species of animals that were domesticated for the same purpose: lama, Lama glama, and elephant (the African bush elephant Loxodonta africana, in Carthage, and the Asian elephant Elephas maximus, in India and South East Asia). In reality, elephants were not domesticated, they were tamed. Taming is not full domestication. The taming of elephants is mentioned as long ago as $4.500 \mathrm{BC}$ in places of the Indus Valley Civilization. The four species, camel, bull/ox, donkey, and horse, were most commonly used as driving forces for different forms of transport' vehicles. The mule is a hybrid between a male ass and a female horse [5]. It is mainly a working animal. It is mentioned in the Bible, at least 3.000 years ago. Horses, donkey, mules, camels, and elephants are still in use today. 
They are also used in the military. However, the muscle force of humans and animals soon became inadequate to supply all the needs of mankind. The power of the wind was discovered as a driving force for ships on the sea and for windmills on land [6]. Later, the power of falling water for water mills was added. As the population of people increased, new power resources were discovered to feed the growing demand; for example, steam power engines, which are external combustion engines (ECEs) [7].

The first use of steam power was mentioned in the first century AD. It is associated with the name of Hero of Alexandria in Roman Egypt. The first steam engine was known as the aeolipile (also known as Hero's engine) [8]. The aeolipile that Hero described is considered to be the first recorded steam engine or steam turbine [9]. Different constructions of steam engines followed over time, by various inventors: in 1551, Taqi al-Din Muhammad ibn Ma'ruf from The Ottoman Empire invented the rudimentary steam engine [10]; in 1606, the Spanish engineer Jerónimo de Ayanz y Beaumont invented, and patented, the steam-powered water pump [11]; and in 1781, James Watt patented the stationary steam engine [12]. Many different constructions of steam engines were invented for numerous tasks in transportation, including the production of goods and transportation of passengers. They were also used for military purposes.

The internal combustion engine (ICE) soon followed, proving to be more compact and powerful than the ECE. These ICEs included turbines and different engines using, for example, liquid hydrocarbons or coal dust (construction of Robert Street in 1794). The Pyréolophore was one of the first ICEs (construction of Joseph Nicéphore Niépce and Claude Niépce in 1807). However, all these inventions were not sufficiently adaptable, technically, to industrial use. Then, in 1823, Samuel Brown patented an ICE that suited the demands of industry. This engine of Brown was later improved. On 12 June 1854, in London, a patent was granted to the Italian engineers Eugenio Barsanti and Felice Matteucci for an ICE that was more or less usable. Since then, many improved constructions of ICEs have followed. In 1872, the first commercial liquid-fueled ICE was invented by an American, George Brayton. In 1879, Karl Benz patented a reliable two-stroke gas engine. All these engines followed almost the same idea. Later, a new idea for a more powerful engine came from a German mechanical engineer (born in Paris), Rudolf Christian Karl Diesel. He developed the internal combustion compressed charge, compression ignition engine in 1892. Initially, the diesel engine was envisaged to become an aviation engine. The diesel engine requires a heavier and more robust construction than a gasoline ICE. The diesel engine requires for fuel compression a heavy rotating flywheel. Because of this it cannot be used successfully in airplanes. The diesel engine was nonetheless widely used and remains in use today as a stationary power engine and in agricultural machines, and road construction vehicles (for example as graders, excavators, bulldozers, etc.). The diesel engine is especially useful as an engine for ships and submarines, where the gasoline engines are low powered. For similar reasons, it 
is used in heavy trucks, locomotives, tanks, and modern automobiles.

Diesel is powerful and economical and can consume (it is depending of modification) the fuels from the gas to the heavy liquid fuel as black mineral oil (mazut). Exhaust gases from liquid-fueled ICEs, including diesel, depend heavily on the fuel used. The exhaust gases from liquid-fueled ICEs can either be very dirty, or almost clean/free from sulfur oxides and nitrogen oxides (NOx), depending on the fuel used.

\subsection{The World Ocean: Chemistry, Geology, Environment and Politically Motivated Statements}

\subsubsection{Total Volume of Water in World Ocean}

The ETOPO1 Global Relief Model, the National Centers for Environmental Information (NOAA) published information about the volumes of the World's Oceans (it is presented in table 1 in ref. [13]). According to information published by the NOAA, the total volume of water in the World Ocean (in cubic kilometers) is $1,335,000,000$. One cubic kilometer is equivalent to $1,000,000,000$ cubic meters and one cubic meter is 1.000 liters, or approximately $1.000 \mathrm{~kg}$. The distribution of water (in cubic kilometers) is as follows: Arctic Ocean 18,750,000, Atlantic Ocean 310,410,900, Indian Ocean 264,000,000, Pacific Ocean 660,000,000, and Southern Ocean 71,800,000. In addition, the South China Sea has 9,880,000 cubic kilometers. The total water in the World Ocean is 1,335,000,000 $\times$ $1,000,000,000,000 \mathrm{~kg}$. There is therefore $1,335,000,000,000,000,000,000$ or 1.335 $\times 10^{21} \mathrm{~kg}$ of water in the ocean. This figure does not include the many cubic kilometers of water in the world seas, such as the Caspian and Dead Seas, and in some big lakes, such as Baikal and others. The ocean covers more than $70 \%$ of the Earth's surface.

\subsubsection{Salinity and Salt Composition of World Ocean}

Seawater has a salinity of $3.5 \%$ (or 35 parts per thousand) on average. Dynamics of the salinity in the World Ocean is presented in [14]. From this paper, it was possible to conclude that measurements were "coincident with much improved salinity sampling over the latter period", and that salinity was and is constant. The salinity through the World Ocean is not uniform in horizontal and vertical directions; however, "the total amount of salt in the ocean is constant on timescales of millions of years" [15]. The concentrations $(\mathrm{mol} / \mathrm{kg})$ of various ions in ocean water are as follows: $\mathrm{Cl}^{-} 0.546, \mathrm{Na}^{+} 0.469, \mathrm{Mg}^{2+} 0.0528, \mathrm{SO}_{4}^{2-}$ 0.0282, $\mathrm{Ca}^{2+}$ 0.0103, $\mathrm{C}_{\mathrm{T}} 0.00206, \mathrm{Br}^{-} 0.000844$, and $\mathrm{Sr}^{2+}$ 0.000091. Of particular interest is the concentration of $\mathrm{C}_{\mathrm{T}} 0.00206$ (the total inorganic carbon: carbon dioxide, carbonic acid, bicarbonate anion, and carbonate; $C_{T}=\left[\mathrm{CO}_{2}{ }^{\star}\right]+\left[\mathrm{HCO}_{3}{ }^{-}\right]+$ $\left[\mathrm{CO}_{3}{ }^{2-}\right]$ ). The latter (given in parentheses) can precipitate with $\mathrm{Mg}^{2+}, \mathrm{Ca}^{2+}, \mathrm{Sr}^{2+}$, and some other divalent/trivalent ions as heavy-soluble or insoluble (in water) salts of carbon dioxide, carbonic acid, or bicarbonate; in other words, as carbonate salts. Today all these ions in above given concentrations are present in water in soluble state. In ocean water, there is $0.063191 \mathrm{~mol} / \mathrm{kg}$ of $\mathrm{Mg}^{2+}, \mathrm{Ca}^{2+}$, and 
$\mathrm{Sr}^{2+}$. This does not take into account $\mathrm{Fe}$ and $\mathrm{Pb}$, and many other elements dissolved in ocean water as divalent/trivalent ions capable of forming heavy-soluble or insoluble (in water) carbonate salts. A concentration of $0.063191 \mathrm{gr} \mathrm{mol} / \mathrm{kg}$ (or roughly g/L, or $\mathrm{g} / \mathrm{kg}$ ) of $\mathrm{Mg}^{2+}, \mathrm{Ca}^{2+}$, and $\mathrm{Sr}^{2+}$ permits additional dissolution of $\mathrm{CO}_{2}$ in ocean water, as indicated by the mass balance and solubility product constants. Precipitation of these salts does not affect the mass balance because they are excluded from the mass balance by precipitation.

\subsubsection{Capacity of World Ocean to Absorb $\mathrm{CO}_{2}$}

The capacity of the World Ocean to absorb $\mathrm{CO}_{2}$ from the air is approximately $0.063191 \mathrm{~mol} \times 1.335 \times 1.021 \mathrm{~kg}$. Taking into account that the gram $/$ mole value of $\mathrm{CO}_{2}$ is 44 , it is possible to dissolve the following quantity of $\mathrm{CO}_{2}$ in the World Ocean: $44 \mathrm{~g} \times 0.063191 \times 1.335 \times 1.021 \mathrm{~kg}=3.712 \times 1.021 \mathrm{~g}$, or $3.712 \times 1.018 \mathrm{~kg}$, or $3,711,839,340,000,000$ tons.

According to an EPA publication (2014) [16], "Global carbon emission from fossil fuels was about 10,000 million metric tons (10,000 million metric tons is 10,000,000,000 tons) (Boden, T.A., Marland, G., and Andres, R.J. (2017). Global, Regional, and National Fossil-Fuel $\mathrm{CO}_{2}$ Emissions. Carbon Dioxide Information Analysis Center, Oak Ridge National Laboratory, U.S. Department of Energy, Oak Ridge, Tenn., U.S.A. doi 10.3334/CDIAC/00001_V2017 [16]). World Ocean capacity is $3,711,839,340,000,000$ tons of $\mathrm{CO}_{2}$. Beyond that, the World Ocean would be unable to absorb any significant amount of $\mathrm{CO}_{2}$. This capacity is $371,183,934$ (about 370,000,000) times the global carbon emission from fossil fuels that existed in 2014. Indeed, the World Ocean capacity to absorb (dissolve) $\mathrm{CO}_{2}$ is much greater if other salts are also taken into account, for example: $\mathrm{LiCl}$, $\mathrm{NaCl}, \mathrm{KCl}, \mathrm{MgCl}_{2}, \mathrm{CaCl}_{2}, \mathrm{SrCl}_{2}$, and other readily soluble (in water) salts present in ocean waters (see equation [17] and the "Compilation of Henry's law constants (version 4.0) for water as solvent" [18]). According to Boden et al. [16], emissions by country are as follows: China 30\%, USA 15\%, European Union 9\%, India 7\%, Russian Federation 5\%, Japan 4\%, and all other countries $30 \%$.

\subsubsection{Evaporation of World Ocean}

Further important information is presented in [14]: "Inferred global changes of $E-P$ over 1950-2010 amount to an increase of $1 \% \pm 0.6 \%$ in net evaporation across the subtropics and an increase of $4.2 \% \pm 2 \%$ in net precipitation across subpolar latitudes". This means that an increase in net evaporation across the subtropics was balanced by "an increase ... in net precipitation across subpolar latitudes". There is no danger that the World Ocean will evaporate and that we will be left on dry-solid ground, nor is there a danger that the World Ocean will be overfilled with water and the "Second Flood" will be a fact because of "Global Warming", as some politicians proclaim. A more important conclusion from the fact of balanced evaporation/precipitation [14] is that natto warming-up and culling-down is constant on the Earth, and hence "Global Warming" is a political fiction [6], [19]. 


\subsection{Local and Global Pollution: Significance and Danger}

Some significant sources of heavy local pollution are presented and discussed in references [19] and [6]. Neither local, national, nor international authorities have reacted boldly toward the contamination of air, water, and soil. In Indonesia, every year, peasants and criminals burn enormous areas of forest, and the resulting smog covers the region, as far as Malaysia and its capital Kuala Lumpur. By 2017, in Greater Kuala Lumpur, also known as the Klang Valley, 7.25 million people [20] were reported to be suffering from this smog, annually [19]. In India, the population of Delhi is suffering from dust and smog contaminated with dioxins [19]. Furthermore, a significant quantity of dioxins has contaminated tobacco and food exported from countries using fair farming [19]. Internationally, nobody seems to react to the intentional setting of fires on Israeli fields, forests, and protected nature reserves by the Palestinians from Gaza. In Kenya, on a recreation beach, a big body of whale was built from rubber sandals that had floated there, all the way from India, via the Indian Ocean. Desperate locals have tried to take action; they have attempted to clean the beaches and attract international and local authorities' opinions to this problem. (Garbage from India is continually polluting the African shores and parts of the Indian and Pacific Oceans). Today, some places in the Indian and Pacific Oceans look like a heavy soup composed of garbage and plastics. Significant damage to sea animals, fish, and sea flora has been caused by pollution that has been produced by city dwellers and peasants, from developing countries and the industrial waste of developed countries.

\section{Sources of Energy to ICEs (Petroleum, Oils from Animal and Vegetable Sources)}

The main source of diesel is mineral oils. Biodiesel still comprises a small volume of all consumed diesel.

\section{Petroleum}

Petroleum is the Latin word for what we mean "mineral oil". There are two main theories regarding the origin of mineral oil: organic and inorganic. It is unwarranted to believe that the genesis of oil was only in prehistoric times, and that it is not happening in present times. Mineral oils have different compositions and many components, depending on the sources of the oils (floristic or faunistic sources). Lipids from animal and vegetable sources are parts of mineral oils. They have a relatively poor content of metal, sulfur, nitrogen, and halogen atoms as part of their molecules. However, several rare lipids from terrestrial plants have fluoride in their molecules and some newly discovered lipids from marine organisms have bromine in their molecules [21], [22]. In molecules of both terrestrial and marine organisms do we find sulfur, nitrogen, and phosphorous. Petroleum/mineral oil usually contains small amounts of metals such as vanadium and osmium, small amounts of metalloids such as selenium and arsenic, 
and moderate amounts of sulfur and nitrogen (up to several percent). Vanadium and compounds thereof (vandates) are very toxic to humans and the environment. An example is porphyrin vanadate which is present in mineral oil, Figure 1 https://www.nature.com/articles/srep05373.pdf. Osmiates, selenates, arsenates, and even cyanides and hydrogen sulfides in the exhaust of ICEs are often overlooked/not taken into account.

Regulations and restrictions related to exhaust gasses from ICEs have mainly focused on sulfur oxides, NOx, carbon monoxide, carbon dioxide, and particles. Yet vanadates, osmiumates, selenates, arsenates, cyanides, and hydrogen sulfides are, in many ways, more toxic to humans and to the environment (including contributing to the greenhouse effect) than sulfur oxides, NOx, and carbon dioxide.

In this regard, it may be interesting to mention some of the compositions of petroleum/mineral oil. Sweet crude oil is composed mainly of hydrocarbons and other molecules that contain elements such as nitrogen (about $0.5 \%$ ), sulfur $(0.5 \%)$, and metals and metalloids such as iron, nickel, copper, and others $(<0.1 \%)$. Light oils can contain up to $97 \%$ hydrocarbons; however, heavier oils and bitumen contain only 50\% hydrocarbons (the remaining 50\% comprise other substances).

Three main categories for the classification of an oil are taken into account: the geographic location where it was drilled, its sulfur content, and its American Petroleum Institute (API) gravity (a measure of density). Furthermore, the color is often taken into account because it shows the maturation grade of the oil.

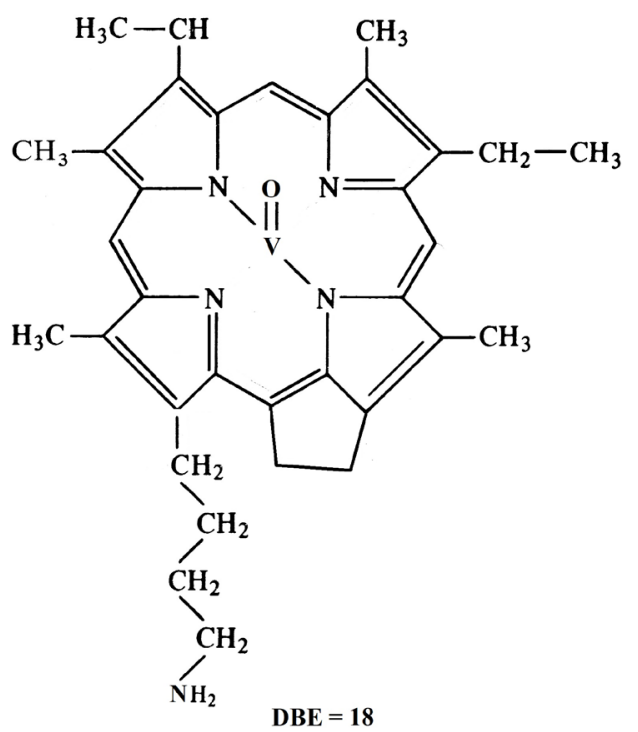

Figure 1. Porphyrin vanadate, redrawn from (Xu Zhao, Quan Shi, Murray R. Gray \& Chunming Xu (2014) New Vanadium Compounds in Venezuela Heavy Crude Oil Detected by Positive-ion Electrospray Ionization Fourier Transform Ion Cyclotron Resonance Mass Spectrometry, Scientific Reports, 4, 5373. DOI: 10.1038/srep05373 https://www.nature.com/articles/srep05373.pdf). 
Translucent light-yellow oils are most mature, while nontranslucent black oils are less mature. The geographic locations are Brent Crude, West Texas Intermediate, and Dubai and Oman. Sulfur contents are as follows: oil with $<0.5 \%$ sulfur is called "sweet" and oil with more than $0.5 \%$ sulfur is called "sour." The API gravity is a comparative gravity of oil to water. Oil is classified as "light" if it floats on top of water and "heavy" if it sinks.

Heavy oils have greater concentrations of sulfur, metals (including heavy metals), and metalloids. Bitumen contains high amounts of sulfur and heavy metals. The sulfur-containing molecules in oils are 3,4-dithiohexane, thiocyclohexane, ethanethiol, thiophene, dibenzothiophene, and others. The nitrogen-containing molecules in oil are pyridine, quinoline, indoline, carbazole, and others.

The compositions of the main elements in mineral oil (by weight \%) are as follows: carbon $83 \%-85 \%$; hydrogen $10 \%-14 \%$; nitrogen $0.1 \%-2 \%$; oxygen $0.05 \%-1.5 \%$; sulfur $0.05 \%-6.0 \%$; and metals $<0.1 \%$.

\section{Ease of Use}

\subsection{Selecting a Template}

First, confirm that you have the correct template for your paper size. This template has been tailored for output on the custom paper size $(21 \mathrm{~cm} \times 28.5 \mathrm{~cm})$.

\subsection{Oils from Animal and Vegetable Sources (Biodiesel) Maintaining the Integrity of the Specifications}

Oils from animal sources are manly oils from different species of whales, walrus, and seals and from the liver of sharks (clade: Selachimorpha or Selachii, class: Chondrichthyes) and rays (class: Chondrichthyes, superorder: Batoidea), and several different species of fish. These oils are relatively rich in vitamins and consist mainly of mono-, di-, and triglycerides [21] [22] [23]. These oils are very poor in molecules containing atoms of sulfur, nitrogen, or metals. These oils can be methylated or ethylated to become a Biodiesel.

Oils from vegetable sources can be divided in several main classes: ether oil, saponified oils, and nonsaponified oils. Here, only saponified oils are of interest. The vegetable oils include rapeseed, line, maize, palm, and many others. They consist of mono-, di-, and triglycerides [21] [22] [23] and are also very poor in molecules containing atoms of sulfur, nitrogen, or metals. These oils can be also methylated or ethylated to become a Biodiesel [24]. However, some oils contain a small amount of chlorophyll, and chlorophyll contains magnesium (Figure 2). Chlorophyll is a magnesium porphyrin complex, and, in this regard, it is similar to porphyrin vanadate; however, magnesium is not a toxic metal. It is also possible to obtain a raffinate of vegetable oils without of chlorophyll. Some small amounts of phytosterols, vitamins, hydrocarbons (n-alkanes), and long chain alcohols (n-1-alcohols) are also present [25], [26] in plants. The combustion of methylated or ethylated vegetable oils as Biodiesel should not result to appearance in exhaust of ICEs sulfur and nitrogen oxides containing gasses. 


\subsection{The Origin of Diesel Fuel}

Diesel is a product of the refinery of petroleum/crude mineral oil. Refining is an industrial process of fractionation by distillation, whereby crude oil is processed and refined into more useful products. Refining is performed in fractionation columns. (Figure 3; the horizontal lines shown are the so-called plates.) Crude petroleum is separated from water and mineral particles, such as clay and sand, and is distilled (refined) to useful products such as petroleum naphtha, gasoline, diesel fuel, asphalt base, heating oil, kerosene, liquefied petroleum gas, jet fuel, and fuel oils [27] [28] [29].

A scheme of the plates in a fractionating column is presented in Figure 4 (three plates are shown). Fractionation takes place on the plates in a defined temperature range; for diesel, it is approximately $200^{\circ} \mathrm{C}-300^{\circ} \mathrm{C}$. The fractionating zone contains many plates. Because the diesel fraction is collected from several plates and the temperature range is quite wide, several substances from mineral oil are present under name "diesel". Here it is to be noted that mineral oil from different origins, and with different maturations and densities, contains different compositions of alkanes, aromatics, nitrogen- and sulfur-containing

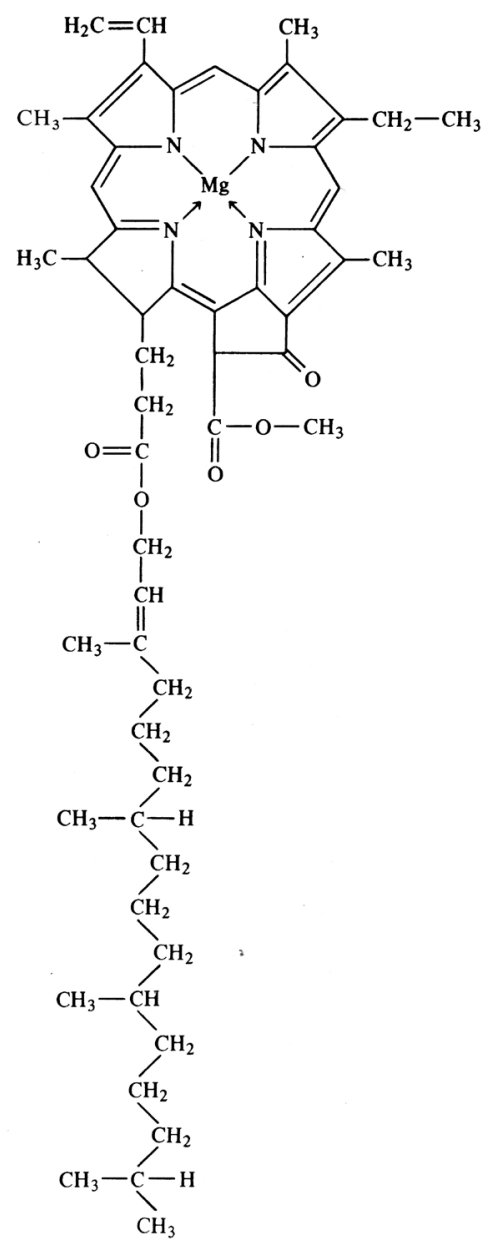

Figure 2, Chlorophyll. 


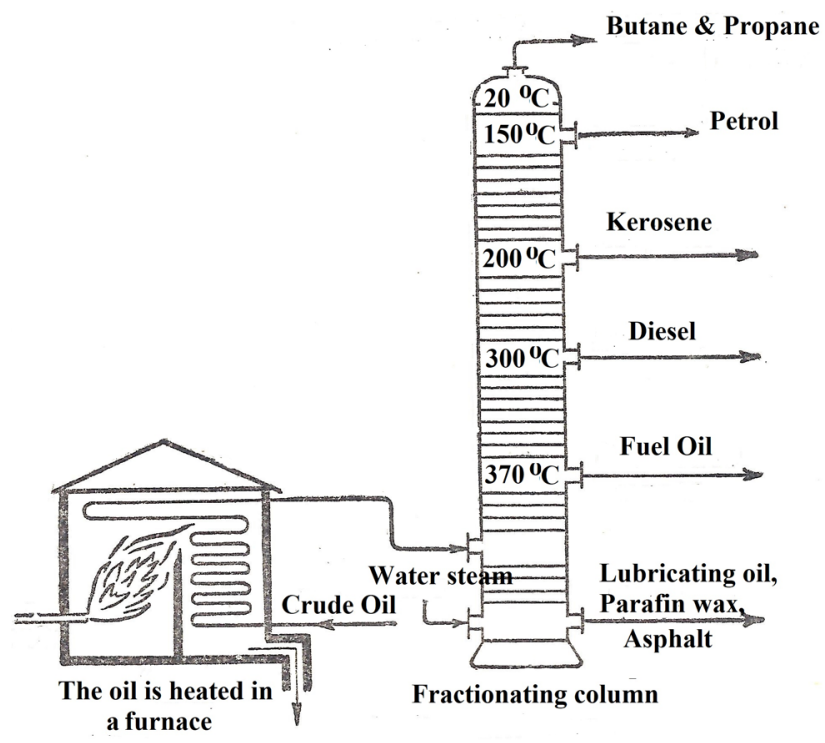

Figure 3. A fractionating column used in refining (scheme).

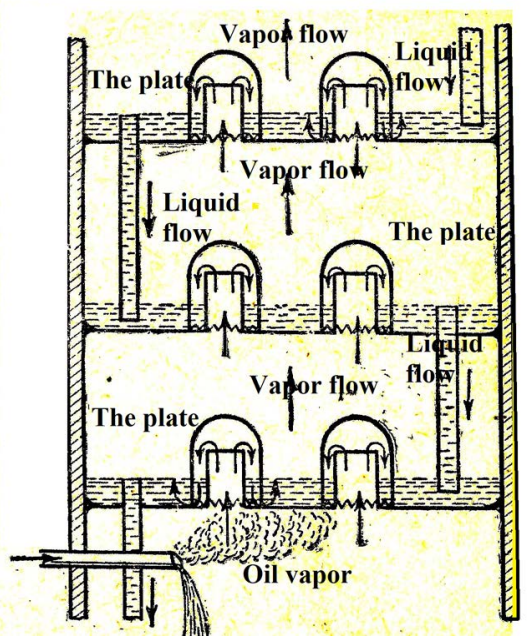

Figure 4. A fractionating column with three plates (scheme).

molecules, and many other different molecules. A further factor determining the composition arises from differences in fractionating technology used by different manufacturers. Hence, diesel is a mixture of many substances-it does not exist as the single molecule "diesel" or a homogenic single substance "diesel".

Nonetheless, there does exist some standardization for diesel, although, from the literature, it is difficult to get the precise percentage of sulfur- and nitrogen-containing substances in distinct diesel. According to the Diesel Fuel Standards and Rulemakings-US EPA

(https://www.epa.gov/diesel-fuel-standards/diesel-fuel-standards-and-rulemakin gs): "Before EPA began regulating sulfur in diesel, diesel fuel contained as much as 5000 parts per million ( $\mathrm{ppm}$ ) of sulfur. EPA began regulating diesel fuel sulfur levels in 1993" ..., and later. "Beginning in 2006, EPA began to phase-in more stringent regulations to lower the amount of sulfur in diesel fuel to $15 \mathrm{ppm}$. This 
fuel is known as ultra-low sulfur diesel (ULSD)". In other countries (other than the USA), other standards and rulemakings are in force. Even in the USA, not all diesel used is of ULSD quality. The use of non-ULSD diesel fuel results in a higher percentage of sulfur oxides and NOx in the exhausts of diesel cars.

\subsection{Oil and Diesel: Costs and Price}

The drilling, recovery, transportation, and refining of oils to diesel all require energy. The amount of required energy depends on many factors, for example: the geological conditions of terrestrial or marine drilling, the means of transportation and distances to be covered, and the technical and economic statuses of the refinery. Some disasters that have resulted in the contamination of the environment have added to the end-price of diesel; oil leakage in the Bay of Campeche of the Gulf of Mexico (3 June 1979-23 March 1980) is an example. A technical fault resulted in a natural disaster, which was followed by a stiff penalty to the oil producing company (placing an economic burden on the price of oil and diesel).

It is difficult to estimate the real buying price per barrel of oil on the market. Earlier, the former Soviet Union sold 1 ton of crude oil to the West for \$9.00. A short while ago, crude oil from Nigeria was sold to the USA for $\$ 5.00$ a barrel. However, the estimated real market price is considered to be $\$ 30.00-50.00$ a barrel. One liter of diesel is sold for $\$ 1.00-3.00$ (depending on the country). Approximately $95 \%$ of the price of diesel constitutes taxes to the states, mainly due to "Global Warming" hysteria. In reality, the loss of energy from a drilling well to a tank of diesel care in terms of the amount of recovered oil is $<10 \%$. A similar amount of energy is lost from the drilling well to the electric power plant. Slightly more energy (about 15\%) is wasted in the production of electricity from coil. Estimates for nuclear power plants are very difficult to present; however, the potential harm from nuclear power plants is obvious.

\section{Electric Vehicles}

The era of electric vehicles did not begin as recently as the past few decades; electric vehicles were well developed more than a century ago. In 1828, Ányos Jedlik, a Hungarian, created a small model car powered by his new electric motor. Robert Davidson from Aberdeen (Scotland) built the first electric car in 1837 [30] [31] [32]. The electrically powered boats were built in Russia, England, France, and Spain. The appearance of the first electrically powered submarines is described in [33]. In 1888, Isaac Peral designed and built the first real electrically powered submarines [34]. Electrically powered vehicles were well adopted to closed rooms, places with restricted ventilation, holds, warehouses, and factories, where easy ignitable or explosive substances were produced. These vehicles are still used today for these purposes.

Previously, heavy lead batteries were used to power these vehicles. The main electrolyte in lead batteries was sulfuric acid. More recently, lithium batteries 
were discovered. Lithium batteries are not as heavy as lead batteries, which led to them being useful in a broad spectrum of devices, from mobile phones and computers to cars and space instrumentation.

\subsection{Diesel versus Electric Power in Cars}

Define The equivalent consumption of energy to deliver fuel and diesel to an ICE is similar to that required to deliver coal and other mineral fuels to electric power plants, which deliver the electricity to electrically driven vehicles. The consumption of energy by electric power plants for delivering electric power and by transmitting, for use in electrical driven vehicles, should be added to the consumption of energy.

Let us now consider the energy conversion efficiency. The energy conversion efficiency is given by $\eta$, where $\eta$ is the ratio between the useful output $\left(\mathrm{P}_{\text {out }}\right)$ of an energy conversion machine and the input $\left(\mathrm{P}_{\text {in }}\right)$. In energy terms,

$\eta=\mathrm{P}_{\text {out } / \text { in }}$

Here, we consider all types of fuels, including diesel, wind, solar, hydro, and nuclear. Electricity generation by the following conversion processes is achieved: in a gas turbine, chemical to electrical is up to $40 \%$; in a gas plus steam turbine, chemical and thermal to electrical is up to $60 \%$; in a water turbine, gravitational to electrical is up to $90 \%$; in a wind turbine, kinetic to electrical is up to $60 \%$; in a solar cell, radiation to electrical is up to $20 \%$; in a fuel cell, chemical to electrical is up to $80 \%$; and in nuclear fission, radioactivity to electrical is up to $40 \%$.

A comparison of diesel and electric motors can be summarized as follows: an electric motor converts electric energy to kinetic energy with 70\% - 90\% energy efficiency, and a diesel motor converts chemical energy to kinetic energy with $60 \%$ energy efficiency. However, whereas the delivery of chemical energy through a diesel motor to wheels may be direct, delivery of energy to an electric motor and from the electric motor to the wheels undergoes some transformations.

Batteries in electric vehicles are charged by direct current (DC). Alternating current (AC) has significant advantages over DC by allowing much longer transmission distances. Transformers are used to increase or decrease voltages. Transformers are used to increase voltages allowing much longer transmission distances.

Power plants usually produce AC. AC to DC conversion is simple, but DC to AC conversion is costly. Transformers are widely used in power delivery. Transformers require AC to operate. Generators are typically used to produce three-phase electrical power. Three-phase electric power enters a transmission substation, which uses large transformers to convert the generator's voltage to high voltages for long-distance transmission. The higher the voltage, the less energy is lost due to resistance of the transmission grid. Voltages for long distance transmission range is from 155.000 to 765.000 volts. At a distribution grid, the voltage must be reduced/stepped down. In power substations, this is usually 
done in three steps, using transformers. Normally, the first step-down gives about 10.000 volts. Later, the "busbar" splits the distribution of power in several directions. After the "busbar", the power is 7.200 volts. It then undergoes further transformation to 240 - 220 or 120 volts, using a transformer drum. DC is required to charge the batteries in electric vehicles; hence, AC must be converted to DC.

The frequent need for the use of transformers has been described. Furthermore, each time electrical power undergoes transformation, up or down, there is a loss of power in the transformers. It is difficult to assign a specific loss for each instance; however, the average is about $50 \%$. This means that for every $1 \mathrm{~L}$ of diesel used in an ICE vehicle, $2 \mathrm{~L}$ of diesel fuel (or an equivalent to diesel) is required to perform the equivalent useful work in an electric vehicle.

\subsection{Environmental Concerns: Diesel versus Electrically Power}

The The disasters at the Chernobyl Nuclear Power Plant (1982: reactor N. 1 partial meltdown; 1986 - reactor N. 4 disaster; and 1991 - reactor N. 2 fire) contaminated large parts of Europe. Radiation from events in 1986, as a radioactive cloud, spread as far north as Norway [35]. After the meltdown, the disastrous reactor N. 4 was initially isolated by hastily building a sarcophagus to protect the environment [36]; however, it was not totally successful [37]. The process of building a new and safer sarcophagus, financed by the European Bank for Reconstruction and Development, commenced in 2010. Chernobyl is located in northern Ukraine. Ukraine has insufficient economic power to support this project. The financial burden, as well as the harm of the radiation, therefore falls on the population of our planet.

The Fukushima disaster in Japan was on the same scale [38]. Recently, in a presentation made this year (2018), the current situation is described as follows: "New source of radioactivity from Fukushima disaster" https://www.sciencedaily.com/releases/2017/10/171002161251.htm. Less harmful, yet not totally without causing harm to the environment, are the hydroelectric power plants, sun battery and wind electric power plants [6].

Prohibition to use the vehicles driven by ICEs and overall introduction of electrically powered cars will require doubling of world electrical energy production. This will increase the use of mineral oil used at electrical power plants and the number of these, will increase the number of nuclear power plant also and by this will increase the harm to humans and environment.

Diesel vehicles, in addition to their exhaust gases, have other negative effects on the environment (due to exploitation and decommissioning). The utilization of used motor oil, rubber, plastics, and accumulators is harmful to the environment. Hybrid vehicles cause similar problems, including in addition those related to the use of electric batteries.

Electrically powered vehicles have a relatively small amount of lubrication oil, but an equivalent amount of rubber and plastics, and numerous electric batteries 
should be used and utilized. The utilization of rubber tires is a common problem for all vehicles. The production and utilization of electric batteries during the use of electrically powered cars and after their decommissioning presents a big problem.

The production of certain metals that are used in some electric batteries can yield materials that are harmful to the environment. In the production of magnesium $(\mathrm{Mg})$, use is made of freons, $\mathrm{SF}_{6}$, and other substances as replacements (published by Tom Tripp-US Magnesium SF6 Replacement Consideration for Primary Magnesium Producers; [39]). In the production of aluminum (Al), use is made of hydrogen fluoride (HF). It is used for producing synthetic cryolite (sodium hexafluoroaluminate, $\mathrm{Na}_{3} \mathrm{AlF}_{6}$ ). It is the molten electrolyte in electrolysis cells used for aluminum production from alumina $\left(\mathrm{Al}_{2} \mathrm{O}_{3}\right)$ [40], [41]. Freons and SF6 are very harmful greenhouse gases. The global warming potential for $\mathrm{SF}_{6}$ is 23,900 times that of $\mathrm{CO}_{2}$ [39]. Some other metals used in electric batteries for electrically powered cars can be more harmful than lead, used for accumulators in diesel cars. Organic liquids used in electric batteries for electrically powered cars are also harmful to humans and the environment.

The best electric batteries can only be recycled/reused up to 1000 times, as opposed to the unlimited (by time) use of a diesel tank in diesel cars. Decommissioning of lead accumulators is a dirty and costly process; however, it is well worked-in today. Decommissioning of batteries for electric cars is a big problem - and a future technological challenge.

\section{Discussion}

Diesel cars are more powerful and economical than electric vehicles, and better suited to harsh climates. Exhaust gases are not so much a function of the construction of the diesel motor in itself, but rather a function of the diesel fuel. A low percentage, or the absence, of sulfur compounds in a diesel fuel will give an exhaust that is low or totally free from sulfur oxides. Diesel fuel from mineral oils should be cleaned of sulfur compounds, otherwise, biodiesel (oils from animal and vegetable sources) should be used.

Solving the problems associated with NOx in diesel exhausts is also associated with chemical treating the fuel. Today, urea is used as an additive to diesel fuel to convert the NOx generated in diesel motors to nitrogen, which is not a harmful gas, although $100 \% \mathrm{NOx}$ to $\mathrm{N}_{2}$ conversion has yet to be achieved. Improvements in the chemistry of additives to diesel fuel should lead to a solution to the problem of NOx in exhaust from diesel motors.

The generation of electricity at sites far away from cities will result in cleaner city environments. There will, however, be dirty environments near power stations. Good air ventilation in cities, without unlawful contamination [19], constitutes the basis of good air quality.

Electric cars (but not hybrid electric cars) do not produce exhaust gases in cities-this is a great advantage of electric cars. However, elsewhere, contami- 
nation will exist due to bad energy conversion efficiency and the need to use more fuel (oil) for the production of electric energy. The recycling of batteries (charge/discharge) for electric cars is limited, which means that during the lifetime of an electric car, many batteries must be used. The production of batteries for electric cars, as well as their later decommissioning, carries significant risks of contamination and harm.

\section{Conclusions}

- It is considered incorrect to say that $\mathrm{CO}_{2}$ from transport and industry emissions into the atmosphere can easily lead to a climate imbalance and "Global Warming".

- For more than 370 million years into the future, the World Ocean will still be capable of absorbing $\mathrm{CO}_{2}$ at the level produced by transport and industry in 2014.

- Contamination of the environment (as it is described in references 6 \& 19) should be recognized as being criminal and punishable.

- Diesel fuel should be improved, and subsequently, diesel engines should satisfy the strict criteria applicable to diesel vehicles.

- Electric cars do have a future; however, today, exploitation of these is predated. The reason for the appearance of electric cars is the needs of electronic and oil producing industries to overcome the overproduction of electronic components and the overproduction of oil.

We conclude with a recommendation. A possible solution to the problem of polluted air in large cities is to revisit public transportation means-more underground transport systems (metros) should be built, and more use should be made of tram and trolleybus transport networks.

\section{Conflicts of Interest}

The authors declare no conflicts of interest regarding the publication of this paper.

\section{References}

[1] Mehrotra, K. (2018) BMW Sued by U.S. Diesel Drivers over Emissions-Test Cheating, In: Fisher Investments Norden.

https://www.bloomberg.com/news/articles/2018-03-27/bmw-sued-for-installing-def eat-devices-in-u-s-diesel-cars

[2] Grubb, P. (2005) Order Perissodactyla. In: Wilson, D.E. and Reeder, D.M., Eds., Mammal Species of the World: A Taxonomic and Geographic Reference, 3rd Edition, Johns Hopkins University Press, 629-630.

[3] Nowak, R.M. (1999) Walker's Mammals of the World. 6th Edition, Johns Hopkins University Press, Baltimore.

[4] Wikipedia. The Free Encyclopedia. https://en.wikipedia.org/wiki/Bull

[5] Encyclopedia Britannica. https://www.britannica.com/animal/mule-mammal

[6] Brondz, I. (2018) To Be or Not to Be...? Part II: Is Global Climate Change a Reality 
or a Means of Slavery? Voice of the Publisher, 4, 1-12.

[7] The American Heritage Dictionary of the English Language. 4th Edition, Houghton Mifflin Company. 2000.

https://www.amazon.com/American-Heritage-Dictionary-English-Language/dp/06 18082301

[8] Wikipedia. The Free Encyclopedia. https://en.wikipedia.org/wiki/Aeolipile

[9] Hero (1899) Herons von Alexandria Druckwerke und Automatentheater = Pneumatica et automata. In: Pneumatika, Book II, Chapter XI, Herons von Alexandria Druckwerke und Automatentheater (in Greek and German). Wilhelm Schmidt (Translator), B.G. Teubner, Leipzig, 228-232.

https://archive.org/details/heronsvonalexandhero

[10] Hill, D.R. and al-HASSAN, A.Y. In: History of Science and Technology in Islam, Engineering in Arabic-Islamic Civilization (This paper was originally written by the late Donald R. Hill in Histoire des sciences arabes, Vol. 3, Ed.; Roshdi Rashed, Paris, 1997. It was edited and expanded by Ahmad Y. al-Hassan for publication under Hill and al-Hassan, "Ingeneria". Storia Della Scienza, Vol. Ill, Capitolo LI. Enciclopedia Italiana, 2002, 647-666. This online text is the third edited version). http://www.history-science-technology.com/articles/articles\%2011.html\#_ftn1

[11] Davids, K. (2016) Religion and Technological Development in China and Europe between about 700 and 1800. Artefact, Techniques, et Sciences Humanies, L' Europe technicienne, XVe-XVIIIe siècle, 4, 287-298.

https://journals.openedition.org/artefact/500

[12] Hills, R.L. (1989) Power from Steam: A History of the Stationary Steam Engine. Cambridge University Press, Cambridge.

[13] National Centers for Environmental Information, Table 1. Volumes of the World's Oceans from ETOPO1. https://www.ngdc.noaa.gov/mgg/global/etopo1_ocean_volumes.html

[14] Skliris, N., Marsh, R., Josey, S.A., Good, S.A., Liu, C. and Allan, R.P. (2014) Salinity Changes in the World Ocean since 1950 in Relation to Changing Surface Freshwater Fluxes. Climate Dynamics, 43, 709-736.

[15] Talley, L.D. (2002) Salinity Patterns in the Ocean. In: MacCracken, M.C. and Perry, J.S., Eds., Volume 1, The Earth System: Physical and Chemical Dimensions of Global Environmental Change. In: Munn, T., Ed., Encyclopedia of Global Environmental Change, John Wiley \& Sons, Ltd, Chichester, 629-640.

https://pdfs.semanticscholar.org/34cc/23181c1a79af9ae4867738c4f93977705c11.pdf

[16] United States Environmental Protection Agency. Global Greenhouse Gas Emissions Data. https://www.epa.gov/ghgemissions/global-greenhouse-gas-emissions-data

[17] Setschenow, J. (1889) Über die Konstitution der Salzlösungen auf Grund ihres Verhaltens zu Kohlensäure. Zeitschrift für Physikalische Chemie, 4, 117-125.

Green, E.J. (1958) A Redetermination of Solubility of Oxygen in Sea Water and Some Thermodynamic Implications of the Solubility Relations.

http://citeseerx.ist.psu.edu/viewdoc/download?doi=10.1.1.898.8035\&rep=rep1\&type $=\mathrm{pdf}$

[18] Sander, R. (2015) Compilation of Henry's Law Constants (Version 4.0) for Water as Solvent. Atmospheric Chemistry and Physics, 15, 4399-4981.

https://www.atmos-chem-phys.net/15/4399/2015/acp-15-4399-2015.pdf

https://doi.org/10.5194/acp-15-4399-2015

[19] Brondz, I. (2017) To Be or Not to Be...? Part I: Is Global Climate Change a Future 
Reality? Voice of the Publisher, 3, 25-33. https://doi.org/10.4236/vp.2017.33003

[20] Wikipedia. https://en.wikipedia.org/wiki/Kuala_Lumpur

[21] Brondz, I. (2005) Lipids, Fatty Acids. In: Worsfold, P.J., Townshend, A. and Poole, C.F., Eds., Encyclopedia of Analytical Sciences, 2nd Edition, University of Oslo, Oslo, Vol. 5, 76-88.

http://www.worldcat.org/title/lipids-fatty-acids/oclc/4934332051\&referer=brief_res ults

[22] Brondz, I. (2016) Lipids, Fatty Acids. In: Reedijk, J., Ed., Reference Module in Chemistry, Molecular Sciences and Chemical Engineering, Elsevier, Waltham, 2nd Edition, 76-88.

[23] Brondz, I. (2002) Review, Development of Fatty Acid Analysis by High-Performance Liquid Chromatography, Gas Chromatography, and Related Techniques. Analytica Chimica Acta, 465, 1-37. https://doi.org/10.1016/S0003-2670(01)01467-2

[24] Gumerov, F.M., Usmanov, R.A., Mazanov, S.V., Gabitova, A.R., Kourdiyukov, A.I. and Zaripov, Z.I. (2017) Theoretical and Experimental Study of Reaction of Transesterification of Vegetable Oils in an Alcohol Environment in the SbCF and SCF Conditions with the Ultrasonic Emulsification of Reaction Mixture and the Use of Heterogeneous Catalysts. International Journal of Analytical Mass Spectrometry and Chromatography, 5, 40-55. https://doi.org/10.4236/ijamsc.2017.52003

[25] Brondz, I., Greibrokk, T. and Aasen, A.J. (1983) n-Alkanes of Hypericum perforatum: A Revision. Phytochemistry, 22, 295-296. https://doi.org/10.1016/S0031-9422(00)80110-7

[26] Brondz, I., Greibrokk, T. and Aasen, A.J. (1983) n-1-Alkohols of Hypericum perforatum. Journal of Natural Products, 46, 940-941. https://doi.org/10.1021/np50030a025

[27] Gary, J.H. and Handwerk, G.E. (1984) Petroleum Refining Technology and Economics. 2nd Edition, Marcel Dekker, New York.

[28] Leffler, W.L. (1985) Petroleum Refining for the Nontechnical Person. 2nd Edition, PennWell Books, Houston.

[29] Speight, J.G. (2014) The Chemistry and Technology of Petroleum. 5th Edition, CRC Press, Boca Raton.

[30] Wikipedia, The Free Encyclopedia. Electric Vehicle. https://en.wikipedia.org/wiki/Electric_vehicle\#Experimentation

[31] Wikipedia, The Free Encyclopedia. History of the Electric Vehicle. https://en.wikipedia.org/wiki/History_of_the_electric_vehicle\#Early_history

[32] Navathe, P. and Prakash, V. (2018) Design of Free Powered Electric Vehicle. International Journal of Modern Trends in Engineering and Research, 5, 79-88.

https://www.ijmter.com/papers/volume-5/issue-3/design-of-free-powered-electric-v ehicle.pdf

https://www.ijmter.com/published-papers/volume-5/issue-3/design-of-free-powere d-electric-vehicle/ https://doi.org/10.21884/IJMTER.2018.5068.QNJRU

[33] Bowers, P. (1999) The Garrett Enigma and the Early Submarine Pioneers. Airlife Publishing, Ltd., 167. https://books.google.no/books?id=ohYiAQAAIAAJ\&redir_esc=y

[34] Marine Insight, News Network (2015) Peral Submarine-The World's First Electric Battery Powered Submarine.

https://www.marineinsight.com/maritime-history/peral-submarine-the-worlds-first 
-electric-battery-powered-submarine/

[35] Medvedev, Z.A. (1990) The Legacy of Chernobyl. W. W. Norton \& Company, New York. http://books.wwnorton.com/books/The-Legacy-of-Chernobyl/

[36] Onishi, Y., Voitsekhovich, O.V. and Zheleznyak, M.J. (2007) Chernobyl-What Have We Learned? The Successes and Failures to Mitigate Water Contamination Over 20 Years. Springer Science \& Business Media, Berlin.

https://www.springer.com/la/book/9781402053481 https://doi.org/10.1007/1-4020-5349-5

[37] U.S. NRC United States Nuclear Regulatory Commission (2014) Backgrounder on Chernobyl Nuclear Power Plant Accident. https://www.nrc.gov/reading-rm/doc-collections/fact-sheets/chernobyl-bg.html

[38] Farell, J. (2018) Fukushima Nuclear Disaster: Lethal Levels of Radiation Detected in Leak Seven Years after Plant Meltdown in Japan. Independent.

https://www.independent.co.uk/news/world/asia/fukushima-nuclear-disaster-radiat ion-lethal-levels-leak-japan-tsunami-tokyo-electric-power-company-a8190981.html

[39] https://www.epa.gov/sites/production/files/2016-02/documents/conf04_tripp.pdf

[40] The Essential Chemical Industry-Online. Hydrogen Fluoride. http://www.essentialchemicalindustry.org/chemicals/hydrogen-fluoride.html

[41] Dahlke, T., Ruffiner, O. and Cant, R. (2016) Production of $\mathrm{HF}$ from $\mathrm{H}_{2} \mathrm{SiF}_{6}$. Procedia Engineering, 138, 231-239. https://doi.org/10.1016/j.proeng.2016.02.080 